\title{
Applying Interactive Planning on Science and Technology Policy in State Personnel Agency
}

\author{
Himsar Silaban ${ }^{\#}$

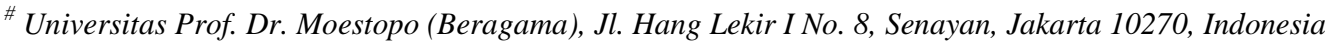 \\ E-mail: himsarsilaban.paper@gmail.com
}

\begin{abstract}
People's stereotypes on the implementation of public services, especially in personnel services in general, particularly in Indonesia, mostly concern with bureaucratic hassle, since it is considered incapable of providing sufficient information, lack of transparency, and slow. The efforts to fix the stereotypes are incessantly conducted by the government through Good Governance in the field of information technology. Today, the role of information technology management must be more strategic in building the personnel data management system. The Government of Indonesia develops an online-based Personnel Service Application System (SAPK) that makes it a center for personnel needs management, career development, retirement, and personnel data update. SAPK is a new opportunity to create intellectual capital and provide a way for employees to contribute to the organization. In this paper, to determine the appropriate action of decision making, the interactive planning method is used as a draft of future design, based on current real conditions. The use of interactive planning method is believed to be the appropriate way to see the possibility of program or activity implementation. The results of this study demonstrate the technological use of Personnel Service Application System (SAPK) makes the personnel management a unified whole and centralized, easily researched and managed. Employees are also encouraged to be more active and independent in self- and knowledge- development. SAPK has the potential to make the time of document processing efficient and to improve the accuracy of data; and to make personnel skill improvement effective and to make decisions making timelier. By using interactive planning, the picture of future planning design is more visible, based on current real issues of State Personnel Agency (BKN).
\end{abstract}

Keywords - Information technology management; Human resource management; Public policy; National civil service agency; Interactive planning.

\section{INTRODUCTION}

People's stereotypes on the implementation of public services, especially in personnel services in general, particularly in Indonesia, mostly concern with bureaucratic hassle, since it is considered incapable of providing sufficient information, lack of transparency, and slow. The efforts to fix the stereotypes are incessantly conducted by the government through Good Governance. Principally, Good Governance is the answer to people's demand for public services that are transparent, accountable, participatory, and lawful [1]. The basic capital to achieve Good Governance is the effective and efficient work management including Human Resources, and technological, economic, social and cultural aspects [2]. The utilization and development of technological capital, particularly the information communication technology in the governance process, is intended to increase the efficiency, effectiveness, transparency and accountability of governance [3]. The government should be able to take advantage of the advances in information technology to improve the ability to process, manage, deliver and distribute information and public services [4], [5].

In Indonesia, with more than 80 central institutions and more than 500 local institutions, if each institution has its own independent and local management information system, it will certainly make islands of information; and accurate and up to date national databases is merely a dream. Hence the standardization of personnel management information system is required, as well functioning as a system that will finish civil administration effectively. This makes the use of information technology in personnel management absolutely necessary. It makes the Information Technology (IT)-based management system become a must [6]. In this paper, to determine the appropriate action of decision making, the interactive planning method is used as a draft of future design, based on current real conditions. The use of interactive planning method is believed to be the appropriate way to see the possibility of program or activity implementation.

The rest of this paper is organized as follow. Section 2 describes Personnel Service Application System (SAPK). 
Section 3 describes related work on information technology management as an effort to optimize and manage the corporate resources. Section 4 presents the research method. Section 5 present results and following by discussion. Finally, the conclusion of this work is described in Section 6.

\section{Personnel Service ApPlication System (SAPK)}

The efforts to establish a reliable personnel management information system and the wish for a transparent and objective personnel data transparent depart from the problems encountered by the State Personnel Agency (BKN). Currently, the data of one civil servant (PNS) is not integrated with other civil servants, often resulting in the data duplication which then leads to inefficiency in handling personnel issues. Thus, BKN feels the need to develop an online Personnel Service Application System (SAPK) using one database of PNS. With a system of personnel management, unified personnel information is expectedly established, to hinder data redundancy and duplication, thus making an accurate and up to date PNS database. Therefore, BKN has built a Personnel Service Application System (SAPK) through which all data related to civil servants can be detected, and personnel services such as the determination of Personnel Index Number (NIP), promotion, Mutation, Retirement and others can be done more effectively and efficiently.

In general, the aim of SAPK development is to establish the latest personnel data in each central or local institution integrated nationally in the Personnel Service Application System so as to improve the personnel services transparently and objectively. SAPK a breakthrough of bureaucratic reform on personnel service through the use of communication and information technology that was initially implemented in 2006 for internal affairs of State Personnel Agency (BKN) (still with the client server application), then in 2008 it was developed at the central and local institutions. The web-based application with the platform of Java technology ran effectively on July 25, 2011 so that personnel service can be conducted anywhere, anytime, and at a very low cost. SAPK is a form of transformation process towards e-government that must be implemented, since through the transformation process the government can optimize the utilization of information technology advances to eliminate barriers in bureaucratic organization, and form a network of management system and work process that allows government institutions to work together to simplify access to all information and public services provided by the government.

Generally, SAPK has the following characteristics: (1) the system is connected online between central BKN, and Regional Offices of BKN, as well as the institutions using the data communication network; (2) the system uses one PNS database used jointly (3) the system uses similar data structure and reference table according to the standard set by central BKN; (4) The system built can be developed according to the needs of the user institutions. Therefore, the electronic-based personnel service is expected to improve the personnel service quality, particularly in terms of personnel data accuracy so that the differences between data from BKN, Ministry, Provincial Personnel Agency (BKP), and District/Municipal Personnel Agency (BKD) can be minimized. The information technology-based Personnel service is one of the requirements, a quick win, of bureaucratic reform. By looking at the afore-mentioned urgency, the information technology-based data integration must be followed by an improvement in the quality of human resources, especially in the field of information technology.

\section{RELATED WORK}

In general, Information Technology Management is understood as an effort to optimize and manage the corporate resources in accordance with the priorities and needs on the basis of technology. McNurlin et al. [7] state that technical requirements such as computers, networks, software, and other technical supports are important in managing organizational resources.

Misra and Akman [8] argue that technology and human resource management (HRM) are relevant and influence each other. An organization that prioritizes its Human Resource (HR) is required to adopt technologies that allow reengineering of the HR function, support organizational change, and design the work instigated by technology, and can support the appropriate managerial climate for the organization [9]. The technology encourages the creation of reliable human resources needs [10].

Snell, Steuber, and Lepak [11] observe that human resource management is capable to meet the challenge and become more strategic, flexible, cost-effective and customeroriented by taking advantage of information technology. Many experts estimate that information technology will be a central tool for all HR practices [12]. Virtual HR management emerges due to the sophistication of IT and increasing HR management options [13]. Thus, IT will gradually affect the organization in providing the state-ofthe-art of human resource services and reduce the costs and hassles generated by conventional management [14], [15].

One impact of IT is that it allows IT-based work creation [16], directs work priorities, and builds organizational competencies [17],[18]. The role of IT in organization also affects the HR function as revealed by Ashbaugh and Miranda [19]; hence the innovation efforts to increase additional value to the organization and the organizational strategy will be easily achieved [20]. Furthermore, Pinsonneault and Kraemer [21] say that the biggest benefit of the IT use in the organizational HR is to provide a broader role for human resources to concentrate on strategic planning of organizational development.

Substantively, IT can facilitate the migration process of human resources management practices [22]. The management encourages the creation of a discipline, called the Human Resource Information System (HRIS) [23]. Another opinion also promotes the blend of IT and HRM, called E-HRM; as an attempt to implement the strategy of HR policies and their practices within the organization through the base of technology [24]. IT-based HR management is fundamentally defined as a systematic procedure to collect, store, maintain, and validate the data on human resource required by the organization [25]; and assist the management in making decisions [26], as well as encourage HR to participate further in the process of their career development [27]. A study by Insight Consulting 
Partners (ICP) notes that HRIS can support the long-term planning in labor planning, prediction of labor requirements, labor allocation, labor qualification and career development [26],[28].

This is the underlying principle that urges State personnel Agency (BKN) to develop the on-line Personnel Service Application System (SAPK), as an effort to manage the human resources data optimally. The Personnel Service Application System (SAPK) is a system that is integrated and connected on-line with the entire institutions to provide personnel services [29]. The system aims to make accurate and update the personnel database nationally; so that the data will be unified nationally and ease the achievement of excellent service.

The BKN Head Regulation No. 14 of 2011 on the Guidelines for Development of Civil Servants Database regulates four fundamental issues associated with the refinement of personnel data. First, Personnel Procurement Application. This application is used as a process to determine the Personnel Index Number (NIP) by basing the activities on the needs of personnel number in each institution, both central and local. Second, Promotion Application. This application is used as the process to determine a promotion, which includes the submission of a structural promotion request. Third, Retirement Setting Application. The use of this application will process a retirement proposal submission when an employee has reached the age of retirement or early retirement filing. Fourth, other Applications: Data Rejuvenation. This application is used to update the data, whether used BKN or by the unit of personnel management institution/BKD, amok others: data of family mutation history, data of office experience history, data of educational history, and other data of personnel mutation.

Through a series of literature studies, Ensher et al. [30] note that the IT-based HR management will have an impact on: (1) reducing the cost and time, (2) transferring selfmanagement to the human resources directly, (3) increasing the readiness for information technology of human resources, (4) integrating human resources with other organizational systems, in particular information system, (5) making HR as part of a strategic business partner. Furthermore, Kettley and Reilly [31] report empirically the potential benefits in three areas, namely: (a) operational efficiency, (b) relational (linkage) impact, (c) transformational impact.

\section{METHODOLOGY}

Interactive planning is used to design the future planning, which is based on the problems encountered at the present. Interactive planning is directed at creating the future the which is based on the belief that an organization's future depends at least as much on what it does between now and then, as on what is done to it [32],[33],[34]. Interactive planning method is derived from the concept of interactivism and is a participatory method dealing with a series of interrelated problems; it is believed that if an action is not done, then the desired future will never happen, and that if an appropriate action is taken, the possibility of the desired future can be achieved [32], [35].

On the other hand, Ackoff [32] also explained that the interactive planning method consists of several planning design. "This planning Consists of the design of a desirable present and the selection or invention of ways of approximating it as closely as possible. It creates its future by continuously closing the gap between where it is at any moment of time and where it would most like to be" [32]. Furthermore, an interactive planning consists of five parts, namely: (1) formulating the mess, (2) ends planning, (3) means planning, (4) the design of implementation, and (5) design of controls [32],[34]. In interactive planning method Ackoff [32],[36] also mentions a few things that support the planning in this method, namely: (1) Participative principle, and (2) Continuity principle, and (3) Holistic principle.

The interactive planning method is selected in this study to determine the actions of decision-making conducted by the State Personnel Agency of the Republic of Indonesia in preparing Indonesian Personnel Management Information System, by taking into account the proper technological management for national employment policy making. This is done by identifying the arising problems and making a policy planning on Personnel Management Information System at the State Personnel Agency (BKN). Furthermore, by using planning method, an interactive planning is prepared in BKN based on the principle of participation, continuity and holistic. Thus, the right solution to the occurring problem can be arranged and the improper actions can be evaluated and improved in terms of policies implementation, including the improvement of public service quality.

\section{INDONESIAN PERSONNEL MANAGEMENT INFORMATION SYSTEM (SIMKRI)}

After the independence of the Republic of Indonesia was proclaimed on August 17, 1945, and the wheels of government had run properly, the first step the Government of the Republic of Indonesia was to establish the state instruments, along with the apparatuses. One of the state instruments is an Agency functioning to monitor the State Administration, particularly for personnel affairs, that was part of the Department of Finance.

Along with the passing of time, in 1945 there was a separation between the Agency and the Department of Finance; the Agency was made as a Department, i.e. Department of Personnel Affairs, headed by the Minister R. Panji Suroso. The institutions incorporated in the Department are: (1) Office of Personnel Affairs located in Yogyakarta, (2) Office of Retirement Affairs located in Bandung, (3) Bureau of Personnel General Affairs located in Jakarta. For approximately five years, the Department of Personnel Affairs ran its duties to assist the President in developing the personnel; it turned out, however, that the Department did not function well, incapable of meeting the government's objectives. Then the Government Regulation No. 32 of 1950 concerning Office of Personnel Affairs was issued and there was a change in the position, function, and the main tasks; the Office was relocated in Jakarta, led by a Head and positioned directly under the Prime Minister. In performing its duties, the Head of the Office of Personnel Affairs was assisted by a Head of Personnel Affairs Bureau who was assisted by a Deputy Head (Kepala Muda).

In conjunction with the changing of era, the Office of Personnel Affairs had been prepared to have operational and 
technical patterns in order to control State Apparatuses after the appointment of the Minister of State Administrative Control. With the establishment of the Ministry, the controlling of personnel and the State Administration was conducted. To ease the controlling, the project was divided into two sectors. First, Sector P one, engaged in the State Administration, particularly regarding the organization or institution, including: Organizational Structure, administration, functions, and management; this sector was entirely handled by the Institute of Public Administration. Second, Sector P two, engaged in personnel affair, namely the improvement of personnel administration, including: personnel development planning, organizing personnel and retirement administrations, organizing supervision, coordination and guidance for the legislation on personnel, whose implementation was entrusted to the State Civil Service Administration Agency (BAKN).

With the enactment of Law No. 18 of 1961 on the principal provisions of personnel, and in order to improve government apparatuses, it was considered necessary to revisit the position, function and main tasks of the Office of Personnel Affairs; the government realized that in order to achieve the National objectives the presence of Civil Servants who are loyal to their duty was require; and to achieve it, the government required a thorough guidance regarding the status, rights and obligations as a State Apparatus. Then based on Government Regulation No. 32 of 1972, the Office of Personnel Affairs was transformed into State Personnel Administration Agency.

The Agency consisted of six bureaus including the Bureau of Personnel Administration in Yogyakarta and the Bureau of Retirement in Bandung. As the implementer of the personnel controlling, the Presidential Decree No. 27 of 1973 was issued, serving as the basis for Re-Registration of Civil Servants (PUPNS) on March 16, 1974. The measure was implemented since at that time the government did not have personnel data that were accurate, complete and trustworthy; thus causing difficulty for personnel development, since: (1) the exact and precise number of Civil Servants was not known. (2) It was difficult to hold proper planning for Civil Servants Development. (3) It was difficult to make a uniform and intact personnel regulations for Civil Servants. From the results of the re-registration of the Civil Servants, the Personnel Card (Karpeg) was made for each Civil Servant, subsequently followed by Husband Card (Karsu) and Wife Card (Karis) later made as the basis to receive Pensions.

In further development, since Law No.18 of 1961 was considered no longer relevant to the needs of the Civil Service development at the time, the Law number 18 of 1961 on the principal provisions of personnel was amended by Law No. 8 of 1974 dated November 6, 1974, on the personnel provisions. Later, for the duties, functions and organization increasingly grew; the Government Regulation No. 32 of 1972 was repealed and replaced by Government
Regulation No. 4 of 1981. Furthermore the position, duties and functions are set by Presidential Decree No. 11 of 1981 , regulating that Personnel Administration Bureau was promoted one structural level higher, becoming the Deputy of Personnel Administrative.

State Civil Service Administration Agency (BAKN) is a non-ministerial government institution, directly under and responsible to the President. BAKN had a two-direction responsibility, namely: (1) technical responsibility to the President; and (2) administrative responsibility to the Minister of State Secretariat/Secretariat of the Cabinet. Therefore, in order to achieve the strategic role of the functions of the State Personnel Agency, with the interactive approach to planning, some efforts are required, consisting the mapping of actual conditions, the principal problems encountered, evaluation and analysis of problems, goalssetting and targets to be achieved, the method to be used, the preparation of the necessary strategic steps, decision-making and the implementation of those decisions. To conduct these efforts some changes indeed need to be done dynamically, adapted to the dynamics of the current real conditions so that these efforts can achieve optimal results yet efficient. The changes cannot be avoided, be it legislation, organization, human resources, existing infrastructure that has been running up to the present (business as usual). Table 1 shows the planning stages of interactive planning.

In the end, technology-based personnel management would be more strategic if addressing the issues of labor productivity; health problems; conducive work place; and the human resources function to focus more on the development of intellectual capital, social capital, and knowledge management to enhance the competitive advantage of the organization [4]. Bussler and Davis [5] assess that many organizations have increased the value of the organization by applying information technology in the management of personnel. The technological use of Personnel Service Application System (SAPK) as the State Personnel Agency itself have made the personnel management in the Republic of Indonesia a unified whole and centralized; easily researched and managed. Employees are also encouraged to be more active and independent in self- and knowledge- development. SAPK has the potential to make the document processing time efficient and improve the accuracy of data; and make the personnel skills improvement effective and make decision-making more timely. SAPK is a new opportunity in creating intellectual capital and provide a way for employees to be able to contribute to the organization [4]. Thus, application of the online Personnel Service Application System (SAPK) as part of the development of personnel management information system in $\mathrm{BKN}$ is expected to support the vision of $\mathrm{BKN}$, i.e. to be a professional and dignified administrator and organizer of personnel management in Indonesia. 


\begin{tabular}{|c|c|}
\hline Formulating the mess & $\begin{array}{l}\text { Before the establishment of SIMKRI : } \\
\text { 1. The certain and precise number of civil servants is not known so that re-registration of civil servants was } \\
\text { held on } 16^{\text {th }} \text { March } 1974 \text {. } \\
\text { 2. The slow personnel services. } \\
\text { 3. The data processing is still manual. } \\
\text { 4. It is difficult to make appropriate planning in terms of civil servants development. } \\
\text { 5. It is difficult to establish uniform and intact personnel regulations for civil servants. } \\
\text { 6. A copy of the personnel document was tardily delivered to BKN, such as the Decree of Civil Servant } \\
\text { Appointment (SK CPNS), the Decree of Promotion (SKKP), the Decree of Work Areas Mutation, and so } \\
\text { 7. It is difficult to provide personnel services due to wide geographical scopes, including remote areas. } \\
\text { 8. The quality of human resources is not adequate }\end{array}$ \\
\hline & $\begin{array}{l}\text { After the establishment of SIMKRI: } \\
\text { 1. The quality of human resources in mastering IT is still limited. } \\
\text { 2. It is known that many civil servants has more than one Personnel Index Number (NIP). } \\
\text { 3. Many copy of the personnel document was tardily delivered to BKN, such as the Decree of Civil Servant } \\
\text { Appointment (SK CPNS), the Decree of Promotion (SKKP), the Decree of Work Areas Mutation, and so } \\
\text { on. } \\
\text { 4. The data accuracy is not well updated, for example, a civil servant who had long retired or dismissed, still } \\
\text { has an active status in BKN because there is no decree of dismissal. } \\
\text { The growing number of civil servants requires fast, precise, and accurate services }\end{array}$ \\
\hline Ends planning & 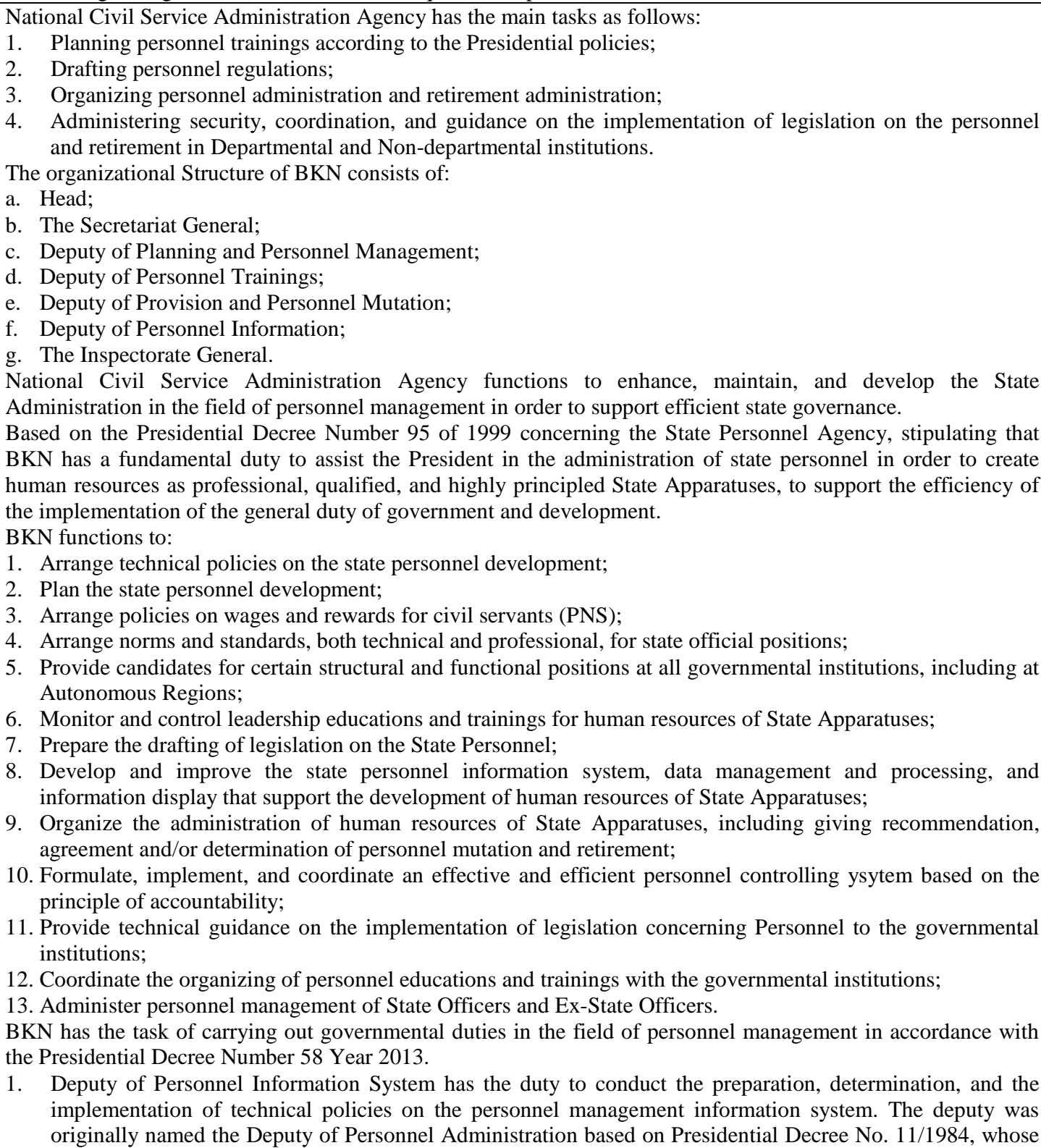 \\
\hline
\end{tabular}




\begin{tabular}{|c|c|}
\hline & $\begin{array}{l}\text { data management was still manual, composed of the Bureau of Personnel Administration I, Bureau of } \\
\text { Personnel Administration II, and Bureau of Personnel Administration III. The alteration was made in } \\
\text { accordance with the demands of personnel service that must be fast, precise, and accurate. The Deputy } \\
\text { consists of: } \\
\text { a. Directorate for Data Processing and Personnel Information has the tasks to implement the formulation } \\
\text { and design of IT-based information system, implement the standardization of the IT-based National } \\
\text { Personnel Service Application System, and implement the personnel data processing, as well as } \\
\text { disseminate the application of office automation; } \\
\text { b. Directorate for the Development of Personnel Information System has the tasks to conduct the } \\
\text { development and maintenance of the devices and the host computer systems, computer networks, and } \\
\text { information systems; } \\
\text { c. Directorate for Personnel Records I has the tasks to conduct the development of personnel records } \\
\text { management system, conduct the recording, archiving, maintenance, and servicing of personnel records } \\
\text { information; } \\
\text { d. Directorate for Personnel Records II has the tasks to conduct the development personnel records } \\
\text { management system, conduct the recording, archiving, maintenance, and servicing of personnel records } \\
\text { information. } \\
\text { The vision of BKN is to be a professional and dignified administrator and organizer of personnel } \\
\text { management. In } 2015 \text {, the mission of BKN is to develop state personnel management system, develop } \\
\text { personnel services system, and develop BKN internal management. } \\
\text { The mission of BKN in the Strategic Plan } 2010-2014 \text { is to develop the personnel management system for } \\
\text { civil servants, formulate policies on civil servants development, and draft the legislation on personnel, } \\
\text { administer excellent personnel services, develop the personnel management information system, organize } \\
\text { the supervision and control of personnel, and conduct BKN internal management. }\end{array}$ \\
\hline Means planning & $\begin{array}{l}\text { 1. Creating a Personnel Service Application System by using computer application system, integrated between } \\
\text { BKN and Central and Local Institutions. } \\
\text { 2. Adjusting the organizational structure in accordance with the demands of the current personnel service. } \\
\text { 3. Improving the quality of IT-based human resources. } \\
\text { 4. Build IT in accordance with the demands of personnel service in the form of software; network setup; } \\
\text { program installation; trainings; and financing. } \\
\text { 5. Optimally make the control of personnel data management planning and implementation efficient. }\end{array}$ \\
\hline Resource planning & $\begin{array}{l}\text { To support the Personnel Management Implementation Program in order to achieve one of the strategic targets set } \\
\text { out in the Strategic Plan of BKN, mandated to the Deputy of Personnel Information, namely "to improve } \\
\text { integrated Personnel Information System", in } 2014 \text { the Deputy of personnel Information obtained a budget of IDR } \\
59,237,280,000,- \text {. } \\
\text { The activities conducted to achieve the targets are: } \\
\text { 1. The construction and development of information system, and the management of personnel database with } \\
\text { the budget allocation of IDR } 6.562 .000 .000,- \text {. In its implementation, up to the end of } 2014 \text { the budget has } \\
\text { been absorbed IDR } 6.109 .822 .160,- \text { or } 93,1 \% \text {, } \\
\text { 2. The management and maintenance of personnel documents and records, with the budget allocation of IDR } \\
\text { 3.900.000.000,-. In its implementation, up to the end of } 2014 \text { the budget has been absorbed IDR } \\
\text { 3.683.780.237,- or } 94,45 \% \text {, } \\
\text { 3. Development, network and information management, with the budget allocation of IDR } 48.775 .280 .000,- \text {. In } \\
\text { its implementation, up to the end of } 2014 \text { the budget has been absorbed IDR } 44.536 .708 .168,- \text { or } 91,3 \% \text {. } \\
\text { The achievement of targets, as indicated in the KPI (Key Performance Indicators) is as follows: } \\
\text { 1. The percentage of accurate and updated PNS database based on personnel principal data is } 90 \% \\
\text { 2. The percentage of governmental institutions that have been integrated to the Personnel Service Application } \\
\text { System (SAPK) is } 90 \% \\
\text { 3. The percentage of governmental institutions using the online Personnel Service Application System (SAPK) } \\
\text { is } 98 \% \\
\text { 4. The time duration to access personnel data record is } 10 \text { minutes } \\
\text { 5. The percentage of processed personnel data record according to NSP is } 92,5 \% \\
\text { 6. The percentage of PNS Electronic Card (KPE) that has been finished is } 98,5 \%\end{array}$ \\
\hline $\begin{array}{l}\text { Design of } \\
\text { implementation }\end{array}$ & $\begin{array}{l}\text { The Deputy of Personnel Information System functions to: } \\
\text { a. Arrange and stipulate technical policies on the personnel management information system; } \\
\text { b. Implement technical policies on the personnel management information system; } \\
\text { c. Provide technical guidance and facilitation of the personnel management information system; } \\
\text { d. Conduct monitoring and evaluation of the personnel management information system; and } \\
\text { e. Do other tasks given by the Head. } \\
\text { The Deputy of Personnel Information System consists of: } \\
\text { 1. Directorate of Data Processing and Personnel Information functions to: } \\
\text { a. Record and finish personnel data problems; } \\
\text { b. Data processing and personnel information; } \\
\text { c. Conduct services, personnel data and information exchange; } \\
\text { d. Formulate and analyze data processing; } \\
\text { e. Arrange the data processing and IT management; } \\
\text { f. Design and analyze personnel information system and develop personnel information system; }\end{array}$ \\
\hline
\end{tabular}




\begin{tabular}{|c|c|}
\hline & $\begin{array}{l}\text { g. Conduct analysis and design the needs of information system and capacity of IT human resources; } \\
\text { h. Conduct technical coordination and design the implementation of personnel application system; } \\
\text { i. Coordinate and integrate the construction and design of data processing application program, including } \\
\text { its supporting data; } \\
\text { j. Design the strategy of database management of reference tables ; } \\
\text { k. Prepare the draft of equipment needs and conduct the maintenance of IT devices and their supporting } \\
\text { wares. } \\
\text { 1. Conduct standardization of system and data processing application program, and give support of their } \\
\text { implementation; and } \\
\text { m. Organize directorate administration. } \\
\text { Directorate of the Development of Personnel Information System functions to: } \\
\text { a. Develop the host computer system; } \\
\text { b. Develop and maintain computer network; } \\
\text { c. Develop information system; and } \\
\text { d. Provide services of directorate administration. } \\
\text { 3irectorate of Personnel Records I functions to: } \\
\text { a. Develop personnel records management system; } \\
\text { b. Archive personnel records; } \\
\text { c. Archive and maintain personnel records; } \\
\text { d. Provide service and facilitate information of personnel records management; } \\
\text { e. Provide services of personnel records information; and } \\
\text { f. Provide services of directorate administration. } \\
\text { Directorate of Personnel Records II functions to: } \\
\text { a. Develop personnel records management system; } \\
\text { b. Archive personnel records; } \\
\text { c. Archive and maintain personnel records; } \\
\text { d. Provide service and facilitate information of personnel records management; } \\
\text { e. Provide services of personnel records information; and } \\
\text { f. Provide services of directorate administration. }\end{array}$ \\
\hline Design of control & $\begin{array}{l}\text { To support the Personnel Management Implementation Program in order to achieve one of the strategic targets set } \\
\text { out in the Strategic Plan of BKN, mandated to the Deputy of Personnel Information, namely "to improve } \\
\text { integrated Personnel Information System", whose accomplishments are indicated by the following indicators:: } \\
\text { - The percentage of accurate and updated PNS database based on personnel principal data } \\
\text { - The percentage of governmental institutions integrated to the Personnel Service Application System } \\
\text { - The percentage of governmental institutions using the online Personnel Service Application System } \\
\text { - ThPK) } \\
\text { - The time duration needed to access personnel data records } \\
\text { - The percentage of PNS Electronic Card (KPE) that has been finished } \\
\text { The arrangement of activity program planning to be carried out by units in the Deputy of Personnel Information is } \\
\text { always based on the evaluation of the activity program implementation conducted in the previous year and get } \\
\text { full attention from the Deputy as a responsible party in achieving the targets mandated by the Head of BKN. }\end{array}$ \\
\hline
\end{tabular}

\section{CONCLUSIONS}

SAPK is a new opportunity in creating intellectual capital and provide a way for employees to contribute to the organization. This is illustrated in BKN's efforts to improve a Personnel Information System, integrated to one another, through the changing of the nomenclature from the Deputy of Personnel Administration to the Deputy of Personnel Information System; and also an increase in the budget into IDR 59.237.280.000, - in 2014. The result of the study using interactive planning shows the mapping of real conditions, the principal problems encountered, the evaluation and analysis of problems, the setting of objectives and targets to be achieved, the application of the method to be used, the preparation of the necessary strategic steps, the decisionmaking and implementation of the decisions that have been set. This is illustrated by the achievement of targets, as indicated in the KPI (Key Performance Indicators) at the State Personnel Agency. First, 90\% of targets are achieved in the preparation of accurate and updated PNS database based on personnel principal data. Second, $90 \%$ of targets are achieved in the integration of governmental institutions with the Personnel Service Application System (SAPK). Third, $98 \%$ of targets are achieved in the number of governmental institutions using the online Personnel Services Application System (SAPK). Fourth, 10 minutes is the time duration needed to access personnel data record. Fifth, 92.5\% of targets are achieved for the processing of employees' scripts. Sixth, $98.5 \%$ of targets are achieved in the completion of PNS Electronic Card (KPE). The result of this study indicates that the technological of Personnel Service Application System (SAPK) at the State Personnel Agency has made the management of personnel in the Republic of Indonesia a unified whole and centralized; easily researched and managed. Employees are also encouraged to be more active and independent in self- and knowledgedevelopment. SAPK has the potential to make the document processing time efficient and improve the accuracy of data; and make the personnel skills improvement effective, and make the decision-makings timelier. 
For the further study, the researcher recommends to complement this interactive planning research with a more thorough analysis, by exploring the reality aspect of Science and Technology Policy in the State Personnel Agency. Systems thinking approach - such as systems dynamic and/or soft systems methodology - is the appropriate approach to get a deeper understanding on the human activity system in terms of public services provision that favors the end users.

\section{ACKNOWLEDGMENT}

This research is supported by University of Prof. Dr. Moestopo (Beragama), Jakarta, Indonesia.

\section{REFERENCES}

[1] Odendaal, N. (2003). Information and communication technology and local governance: understanding the difference between cities in developed and emerging economies. Computers, Environment and Urban Systems, 27(6), 585-607.

[2] Rahul, D. (2016). Societal impacts of information and communications technology. IIMB Management Review, In Press, Corrected Proof, Available online 22 April 2016. doi:10.1016/j.iimb.2016.04.002

[3] Welch, E.W. \& Feeney, M.K. (2014). Technology in government: How organizational culture mediates information and communication technology outcomes. Government Information Quarterly, 31(4), 506-512.

[4] Lengnick-Hall, M. L., \& Moritz, S. (2003). The impact of e-HR on the human resource management function. Journal of Labor Research, 24(3), 365-379.

[5] Bussler, L., \& Davis, E. (2001). Information systems: The quiet revolution in human resource management. Journal of Computer Information Systems, 42(2), 17-20.

[6] Sutriadi, R. \& Wulandari, A. (2014). Towards a Communicative City: Enhancing Urban Planning Coordination by the Support of Information and Communication Technology. Case Study Bandung Metropolitan Area, Indonesia. Procedia - Social and Behavioral Sciences, 135, 76-81.

[7] McNurlin, Barbara et al. (2009). Information Systems Management in Practice (8th ed.). Prentice Hall.

[8] Misra, Alok., dan Akman, Ibrahim. (2010). Information technology in human resource management: An empirical assessment. Public Personnel Management. Volume 39 No. 3 Fall 2010.

[9] Hempel, P.S. (2004). Preparing the HR profession for technology and information work. Human Resource Management, Issue2-3, 163-177.

[10] Buckley, P; Minette, K.; Joy, D; and Michaels, J. (2004) The use of an automated employment recruiting and screening system for temporary professional employees: A case study. Human Resource Management, Issue 2-3, 233-241.

[11] Snell, S. A., Stueber, D. and Lepak, D. P. (2002). Virtual HR Departments: Getting out of the middle. In R. L. Heneman and D. B. Greenberger (Eds.), Human resource management in virtual organizations, pp 81-101, CT: Information Age Publishing.

[12] Kovach, K.A. \& Cathcart, C.E. (1999). Human Resource Information System (HRIS): Providing business with rapid data access, information exchange, and strategic advantage. Public Personnel Management, 28(2), 275-282.

[13] Lepak, D.P. \& Snell, S.A. (1998). Virtual HR: Strategic human resource management in the 21st century. Human Resource Management Review, 8 (3), 215-234.

[14] Ball, K.S. (2001). The use of human resource systems: a survey. Personnel Review, 30 (6), 677-93.

[15] Niederman, F. (1999). Global information systems and human resource management: A research agenda. Journal of Global Information Management, 7(2), 33-39;
[16] Othman, R. and The, C. (2003). On developing the informated workplace: HRM issues in Malaysia. Human Resource Management Review, 13 (3), 393-406.

[17] Bergenhenegouwen, G.J. H.F.K. ten Horn, and Mooijman, E.A.M. (1996). Competence Development - A Challenge for HRM Professionals: Core competencies of organizations as guidelines for the development of employees. Journal of European Industrial Training, 20(9), 29-35;

[18] Pickett, L. (1998). Competencies and managerial effectiveness: Putting competencies to work. Public Personnel Management, 27(1), 103-115.

[19] Ashbaugh, S. \& Miranda, R. (2002). Technology for Human Resource Management: Seven Questions and Answers. Public Personnel Management, 31(1), 7-20.

[20] Shrivatsava, S. and Shaw, J. B. (2003). Liberating HR through technology. Human Resource Management, 42, 3, pp 201-222.

[21] Pinsonneault, A. and Kraemer K. (1993). The impact of information technology on middle managers. MIS Quarterly, September, 271-292; Berardine, T. (1997). Human resource information systems improve management decision-making. Canadian Manager, 22(4), 17-18; Totty, P. (2001). Human resources information systems. Credit Union Magazine, 67(8), 53-55.

[22] Mei, Y.M.; Lee, S.T. and Al-Hawamdeh, S. (2004). Formulating a communication strategy for effective knowledge sharing. Journal of Information Science, 30(1), 12-22.

[23] Beaumont, John R., Kinnie, N. J., Arthurs, A. J. \& Weatherall, C. B. (1992). Information technology and personnel management: issues and educational implications. Unpublished paper, (School of Management, University of Bath).

[24] Snell, S. A., Pedigo, P.R., Krawlec, G.M. (1995). Managing the impact of information technology on human resource management In Ferris, G., Rosen, S. and Barnum, D. (Eds) Handbook of Human Resource Management. Oxford: Blackwell.

[25] Walker, A.J. (1982). HRIS Development. Van Nostrand Reinhold, New York.

[26] Kovach, K.A., Hughes, A.A., Fagan, P., \& Maggitti, P.G. (2002). Administrative and strategic advantages of HRIS. Employment Relations Today, 29(2), 43-48.

[27] Parry, E., Tyson, S. (2007). Technology in HRM: the means to become a strategic business partner. Human Resource Management: A critical text. 3rd ed., chap. 13, pp. 235-249.

[28] Insight Consulting Partners (ICP) (2003). The impact of implementing an HRIS: Are you ready for a change? Retrieved on October 7, 2003 from http://www.insightcp.com/res_09.html

[29] Peraturan Kepala BKN No. 14 tahun 2011. http://www.bkn.go.id/regulasi. Accessed on 16 April 2015

[30] Ensher, E., Nielson, T., Grant-Vallone, E. Tales from the hiring line: effects of the internet and technology on HR processes. Organizational Dynamics, 2002, Vol. 31, No. 3, pp. 224-44. ISSN 0090-2616.

[31] Kettley, P., Reilly, P. (2003). e-HR: An Introduction. Report 398. London: Institute of Employment Studies.

[32] Ackoff, RL. (2001). A Brief Guide to Interactive Planning and Idealized Design. May 31. Lancaster

[33] Ackoff and Pourdehnad J. (2001). Systems Research and Behavioral Science. May-June 2001, Vol. 18, Iss. 3, 199-205.

[34] Asmu'i; Fitriati, Rachma. (2014). Applying Interactive Planning on Leadership in the Organization: The Case of Transforming Public Transport Services in Banjarmasin, Elsevier Procedia - Social and Behavioral Sciences 115 (2014) 283 - 295. www.sciencedirect.com. doi: 10.1016/j.sbspro.2014.02.436

[35] Lumbo, Dona A. (2007). Applications of Interactive Planning Methodology. University of Pennsylvania Scholarly Commons Master of Science in Organizational Dynamics Theses.

[36] [36] Ackoff (1981). Creating the Corporate Future. Plan or be Planned for. New York: Wiley. 